\title{
Exploring the Motivation of Employees in a Firm: A Case-Study
}

\author{
Igor Klopotan, Trina Mjeda, Petar Kurečić \\ University North, Koprivnica, Croatia
}

\section{Abstract}

Background: General concept of motivation, which include the motivational techniques and human resources management as a prerequisite for the most important intangible asset is related to the company performance. Objectives: we build on the conceptual model examining the respondents' attitudes about the influence of various parameters on better business performance and work atmosphere. In addition, we also examine the attitudes towards the impact of motivation, company management, and communication on employee satisfaction. Methods/Approach: Difference in the perception of essential parameters such as motivation, communication, leadership model, and personnel management within a company, over groups of respondents differentiated by gender and age is tested using Kolmogorov-Smirnov test. Results: The results obtained by this research conducted from an employee point of view, detect the difference in the perception of the parameters of motivation, communication, leadership and personnel management, and their impact on employee satisfaction. Conclusions: Our empirical research results clearly pinpoint the link between successful application of motivational techniques, quality of the leadership and employee satisfaction.

Keywords: motivation, leadership, communication, small and medium-size firms, employees, CAWI method, management

JEL classification: M12, D83, L26

Paper type: Research article

Received: Feb 09, 2018

Accepted: Feb 25, 2018

Citation: Klopotan, I., Mjeda, T., Kurečić, P. (2018), "Exploring the Motivation of Employees in a Firm: A Case-Study", Business Systems Research, Vol. 9, No. 1, pp. 151160.

DOI: $10.2478 / \mathrm{bsrj}-2018-0012$

\section{Introduction}

The company's success is related to the quality of performance activities such as: rewarding employees, the making of a favorable organizational climate and culture, and the programs of studying and training (Horvat et al., 2015). Furthermore, certain studies also uncover the connection between organization's success and its dependence on employees-related factors such as: job security, job satisfaction, loyalty to the organization, knowledge creation, and the manager's ability and their attitude towards employees (Mitreva et al., 2012). 
Motivation techniques are generally divided into extrinsic and intrinsic, whereby extrinsic motivation instruments can be direct (salaries, royalties and travel expenses) and indirect (social benefits, education, insurance and other various benefits) (Kehoe et al., 2013). Some authors suggest that financial rewards have become obsolete as motivation factors, emphasizing the role of indirect awards such as seminars, courses and participation in projects, among many others (Lazaroiu, 2015). Although the literature regarding this topic can be very heterogeneous, we used the general concept of motivation, which include the motivational techniques and human resources management as a prerequisite for the most important intangible asset.

According to the analysis of other author's studies and existing scientific knowledge, in this study, we build on the conceptual model examining the respondents' attitudes about the influence of various parameters on better business performance and work atmosphere. In addition, we also examine the attitudes towards the impact of motivation, company management, and communication on employee satisfaction.

\section{Literature review}

Motivation techniques used to support organization members can be seen as extrinsic and intrinsic. Therefore, incentives and benefits available to managers can be used very effectively to improve the employee performance. In transitional or post-transitional markets such as Croatian, the importance of different non-tangible motivation techniques has not yet been acknowledged enough, although there is a vast body of research confirming that thesis. As some research present, it is often more efficient to intrinsically motivate employees, since they can accomplish different tasks without consuming additional resources (Joo et al., 2010). Additionally, "a variety of extrinsic constraints can undermine intrinsic motivation and creativity, including expected reward, expected evaluation, surveillance, competition, and restricted choice" (Yoon et al., 2015). Furthermore, when addressing the role of leadership, its importance has to be emphasized regardless of organization's aim and interests - any organization that employs human power needs a good leader to be able to work effectively (Jerry, 2013). An organization with an effective leader should also address the question of an "effective follower", thus emphasizing the vital function of employee training and development of different human resources management techniques (Yang et al. 2014; Jha et al., 2016).

Danish et al. (2015) studied the effects of reward system among the bank employees in Lahore, Pakistan, measuring the level of performance the employees demonstrate towards their organizations when they are intrinsically rewarded. The authors used the method of self-administered questionnaires and applied correlational explanatory research design. The research findings revealed a positive relationship among intrinsic rewards and task performance, with both intrinsic and extrinsic motivation and also job satisfaction mediating the relationship (Danish et al., 2015). Moreover, studies aimed at measuring the effect of motivation on employee performance in the public sector, have discovered similar findings on motivation techniques that could also work not only as a motivational tool for achieving more effective and satisfied workers, but also as an additional tool during the employee recruitment phase (Liv et al., 2015).

Additionally, based on a survey within two age groups of employees in Slovenia, Rožman et al. (2017) studied the differences between the motivation and satisfaction of employees, using the Mann-Whitney $U$ test. Their findings confirm the existence of differences between two age groups in the motivation incentives and 
workplace satisfaction. Moreover, their research revealed that older employees are "more motivated by flexibility in the workplace; autonomy at work; good interpersonal relationships in the workplace; the possibility of working at their own pace; respect among employees; equal treatment of employees regardless of their age" (Rožman et al., 2017). Obviously, authors have concluded that motivation and satisfaction change as individuals age.

Obviously, there is a lack of consensus among different studies regarding the importance of various motivational techniques and their benefits, since there are studies that confirm the positive relationship between motivation and job satisfaction (e.g., Liu et al., 2008; Liu, 2009; Vandenabeele, 2009), and others that have not confirmed the existence of a significant relationship between the two (such as Moynihan et al., 2007). Nevertheless, the authors of this research consider the field of motivational techniques, leadership quality and employee satisfaction important in running business effectively, especially when considering transitional and posttransitional countries that are still able to significantly improve human resources management in their organizations.

\section{Methodology}

Data

The database of companies consisted of 300 companies selected in a random sample from the Croatian Chamber of commerce directory. In total 87 respondents answered the interview, which represents $29 \%$ of the sample. Among the companies that participated in the survey, $64 \%$ were SMEs, and $36 \%$ were large companies. Most of the companies were registered in Zagreb, Croatian capital city, while smaller number of companies were registered in Split, Osijek, Rijeka and Dubrovnik. Most of the companies were from the primary and secondary sector (56\%), while the rest of companies were operating in tertiary and quarterly sector.

\section{Research instrument}

The target population of this survey are respondents who are or were employed. For the empirical analysis of this study, we collected data from the sample that was comprised from University North students who are studying and working. The research was carried out using CAWI (Computer-assisted web interviewing), and online questionnaire was sent out in a form of link to the e-mail database that was accessible for this research. The survey was composed of a set of statements to which examinees responded by expressing their agreement or disagreement, using a five-degree Likert scale, determined by a "completely agree" to "completely disagree" statements.

\section{Statistical analysis}

The internal consistency measure, conducted over control question, resulted in Cronbach Alpha reliability coefficient 0.586, whilst the number of items was three. We concluded that the attitudes of respondents can be explored by the proposed control questions. Testing for the distribution normality among all the parameters was carried out by Kolmogorov-Smirnov test for normal distribution. Our findings allow us to reject the zero hypotheses stating that all the parameters have a normal distribution, since all the parameters are statistically significant $(0.0000<0.05)$. In as much as the assumption of normality is not met, we will use the Kruskal-Wallis hypothesis test, and present the results in the following tables. Reliability analysis was conducted using Cronbach's alpha coefficients. The analysis of the internal consistency reveals that the Cronbach's Alpha reliability coefficient is 0.795 , while the number of items was seven. We respected the 
recommendations that "internal consistency coefficients of 0.70 or higher are considered to indicate adequate reliability" (Kim et al., 2008). Therefore, we can conclude that the selection of parameters with relatively high consistency allows us to measure the attitudes of the respondents.

\section{Results}

The structure of sample by gender and age shows that most respondents are female $(66 \%)$ and the majority of respondent's average age is up to 25 years $(55.17 \%)$. The share of the respondents under 30 years of age is $20.68 \%$, and above 30 years of age is $24.15 \%$.

The descriptive statistics of evaluated attitudes of respondents on the importance of particular parameters are presented in Table 1.

According to our findings, the highest rated parameter is "Good communication affects a better working environment", and the worst rated parameter is "Personnel policy affects the company's business performance". An overwhelming majority, $97 \%$ of respondents find that motivation is essential when working in a company, while the same percentage of respondents agree that the way they communicate within a company is essential. The leadership model was assessed as essential by $90 \%$ of the respondents.

Table 1

Research instrument description (Likert 1-5), and descriptive results

\begin{tabular}{ll}
\hline Item & Mean (St.Dev.) \\
\hline Motivation affects the company's business performance & $4,55(0,605)$ \\
Motivation affects a better working environment & $4,59(0,691)$ \\
Leadership model affects the company's business performance & $4,69(0,535)$ \\
Leadership model affects the better working environment & $4,53(0,790)$ \\
Good communication affects the company's business performance & $4,69(0,513)$ \\
Good communication affects a better working environment & $4,80(0,546)$ \\
Personnel policy (staff selection and management) affects the & $4,38(0,796)$ \\
company's business performance & \\
\hline
\end{tabular}

Source: Authors' work

Along with the proposed parameters measuring the influence of different variables on better business performance and working environment, our survey also comprised three control questions, which will be used to investigate the relevance of individual parameters between groups of respondents. The following control questions are: (i) Is motivation important for working in a company?, (ii) Is the leadership model important for working in a company?, and (iii) is the communication culture within a company important for working in that company?

Table 2 provides the statistically significant difference in the perception of essential parameters such as motivation, communication, leadership model, and personnel management within a company, over groups of respondents differentiated by gender and age. At 5\% confidence level these are: (i) Good communication affects a better working environment, (ii) Good communication affects the company's business performance, and (iii) the control question "Is the communication culture within a company important for working in that company?". At $10 \%$ confidence level these are: (i) "Is the leadership model important for working in a company?" and (ii) Personnel policy (staff selection and management) affects the company's business performance. 
Table 2

Kruskal-Wallis test for different groups

\begin{tabular}{|c|c|c|c|}
\hline Item & Chi-Square df & & np. Sig. \\
\hline $\begin{array}{l}\text { Is the communication culture within a company } \\
\text { important for working in that company? }\end{array}$ & 3.84 & 1 & $0.05^{* *}$ \\
\hline $\begin{array}{l}\text { Good communication affects the company's } \\
\text { business performance }\end{array}$ & 4.64 & 1 & $0.031^{* *}$ \\
\hline $\begin{array}{l}\text { Good communication affects a better working } \\
\text { environment }\end{array}$ & 3.90 & 1 & $0.048^{* *}$ \\
\hline $\begin{array}{l}\text { Is the leadership model important for working in } \\
\text { a company? }\end{array}$ & 3.02 & 1 & $0.082 *$ \\
\hline $\begin{array}{l}\text { Personnel policy (staff selection and } \\
\text { management) affects the company's business } \\
\text { performance }\end{array}$ & 7.73 & 3 & $0.052 *$ \\
\hline
\end{tabular}

Note: ${ }^{* * *}$ statistically significant at $1 \%,{ }^{* *}$ statistically significant at $5 \%,{ }^{*}$ statistically significant at $10 \%$

Source: Authors' work

The research findings presented in Table 3 are determined by the control question "Is motivation important for working in a company?". Clearly, there is a statistically significant difference in the perception of the key parameters of motivation, communication, leadership model, and personnel management within the company. At $1 \%$ confidence level this is: Motivation affects the company's business performance, and at $5 \%$ confidence level it is: Motivation affects a better working environment.

Results identified by the control question: „Is the leadership model important for working in a company?" are presented in Table 4. The Kruskal-Wallis test indicates that there is a statistically significant difference in the perception of the key parameters of motivation, communication, and leadership model, as well as personnel management within the company. At $1 \%$ confidence level this is: Motivation affects the company's business performance. At a level of $5 \%$ confidence this is: Leadership model affects the better working environment.

Table 3

Kruskal-Wallis test for different groups

\begin{tabular}{llll}
\hline Item & Chi-Square & df & Asymp. Sig. \\
\hline $\begin{array}{l}\text { Motivation affects the company's business } \\
\text { performance }\end{array}$ & 7.32 & 1 & $0.007^{* * *}$ \\
$\begin{array}{l}\text { Motivation affects a better working } \\
\text { environment }\end{array}$ & 5.27 & 1 & $0.022^{* *}$ \\
\hline
\end{tabular}

Note: ${ }^{* * *}$ statistically significant at $1 \%,{ }^{* *}$ statistically significant at $5 \%,{ }^{*}$ statistically significant at $10 \%$.

Source: Authors' work

Table 4

Kruskal-Wallis test for different groups

\begin{tabular}{lcrrr}
\hline Item & Chi-Square & df & & Asymp. Sig. \\
\hline $\begin{array}{l}\text { Leadership model affects the company's } \\
\text { business performance }\end{array}$ & 7.59 & 1 & $0.006^{* * *}$ \\
$\begin{array}{l}\text { Leadership model affects the better working } \\
\text { environment }\end{array}$ & 5.94 & 1 & $0.015^{* *}$ \\
\hline
\end{tabular}

Note: ${ }^{* * *}$ statistically significant at $1 \%,{ }^{* *}$ statistically significant at $5 \%,{ }^{*}$ statistically significant at $10 \%$

Source: Authors' work 
The results provided in Table 5 are defined by the control question "Is the communication culture within a company important for working in that company?" The results implicate there is a statistically significant difference in the perception of the essential parameters such as motivation, communication, leadership model and personnel management within the company. At 1\% confidence level these are: (i) Motivation affects the better working environment, (ii) Leadership model affects the better working environment and (iii) Good communication affects the company's business performance. At a level of $5 \%$ confidence this is: Leadership model affects the company's business performance.

Table 5

Kruskal-Wallis test for different groups

\begin{tabular}{lrrr}
\hline Item & Chi-Square & df & Asymp. Sig. \\
\hline $\begin{array}{l}\text { Motivation affects the better working } \\
\text { environment }\end{array}$ & 8.19 & 1 & $0.004^{* * *}$ \\
$\begin{array}{l}\text { Leadership model affects the company's } \\
\text { business performance }\end{array}$ & 4.76 & 1 & $0.029^{* *}$ \\
$\begin{array}{l}\text { Leadership model affects the better working } \\
\text { environment }\end{array}$ & 7.61 & 1 & $0.006^{* * *}$ \\
$\begin{array}{l}\text { Good communication affects the company's } \\
\text { business performance }\end{array}$ & 6.80 & 1 & $0.009^{* * *}$ \\
\hline
\end{tabular}

Note: ${ }^{* * *}$ statistically significant at $1 \%,{ }^{* *}$ statistically significant at $5 \%,{ }^{*}$ statistically significant at $10 \%$

Source: Authors' work

Table 6

Partial correlation table for the paired variables

\begin{tabular}{|c|c|c|c|c|c|c|c|}
\hline & $\begin{array}{l}\text { Motivation } \\
\text { affects the } \\
\text { company's } \\
\text { business } \\
\text { performance }\end{array}$ & $\begin{array}{l}\text { Motivation } \\
\text { affects a } \\
\text { better } \\
\text { working } \\
\text { environment }\end{array}$ & $\begin{array}{l}\text { Leadership } \\
\text { model affects } \\
\text { the company's } \\
\text { business } \\
\text { performance }\end{array}$ & $\begin{array}{l}\text { Leadership } \\
\text { model } \\
\text { affects the } \\
\text { better } \\
\text { working } \\
\text { environment }\end{array}$ & $\begin{array}{l}\text { Good } \\
\text { communication } \\
\text { affects the } \\
\text { company's } \\
\text { business } \\
\text { performance }\end{array}$ & $\begin{array}{l}\text { Good } \\
\text { communication } \\
\text { affects a better } \\
\text { working } \\
\text { environment }\end{array}$ & $\begin{array}{l}\text { Personnel } \\
\text { policy (staff } \\
\text { selection and } \\
\text { management) } \\
\text { affects the } \\
\text { company's } \\
\text { business } \\
\text { performance }\end{array}$ \\
\hline $\begin{array}{l}\text { Motivation affects the } \\
\text { company's business } \\
\text { performance }\end{array}$ & 1 & & & & & & \\
\hline $\begin{array}{l}\text { Motivation affects a } \\
\begin{array}{l}\text { better } \\
\text { environment }\end{array}\end{array}$ & $0.435^{*}$ & 1 & & & & & \\
\hline $\begin{array}{l}\text { Leadership model } \\
\text { affects the company's } \\
\text { business performance }\end{array}$ & $0.363^{*}$ & $0.277^{* *}$ & 1 & & & & \\
\hline $\begin{array}{l}\text { Leadership model } \\
\text { affects the better } \\
\text { working environment }\end{array}$ & $0.433^{*}$ & $0.380^{*}$ & $0.466^{*}$ & 1 & & & \\
\hline $\begin{array}{l}\text { Good communication } \\
\text { affects the company's } \\
\text { business performance }\end{array}$ & $0.394^{*}$ & $0.368^{*}$ & $0.482^{*}$ & $0.490 *$ & 1 & & \\
\hline $\begin{array}{l}\text { Good communication } \\
\text { affects a better } \\
\text { working environment }\end{array}$ & 0.187 & $0.447^{*}$ & 0.115 & $0.369 *$ & $0.402 *$ & 1 & \\
\hline $\begin{array}{l}\text { Personnel policy (staff } \\
\text { selection and } \\
\text { management) affects } \\
\text { the company's } \\
\text { business performance }\end{array}$ & 0.120 & 0.090 & $0.291^{* *}$ & $0.363^{*}$ & 0.086 & $0.313^{* *}$ & 1 \\
\hline
\end{tabular}

Note: ${ }^{* * *}$ statistically significant at $1 \%,{ }^{* *}$ statistically significant at $5 \%,{ }^{*}$ statistically significant at $10 \%$

Source: Authors' work

In order to avoid the influence of other variables on the observed pair of variables in the model, we calculated the partial correlation coefficients among the pairs of variables, controlling for the effects of the third variable, i.e. three control questions: (i) Is motivation important for working in a company?, (ii) Is the leadership model important for working in a company?, and finally, (iii) Is the communication culture 
within a company important for working in that company? (see Table 6). Although there is a statistically significant correlation between multiple pairs of variables, the correlation coefficient indicates a weak link between the following variables: (i) Good communication affects the company's business performance and Leadership model affects the company's business performance; and (ii) Good communication affects the company's business performance and Leadership model affects the better working environment.

\section{Discussion}

Our overall research findings resulted in statistically significant difference in the perception of the parameter of motivation, communication, leadership model and staff management with the following parameters: (i) Good communication affects a better working atmosphere, (ii) Good communication affects the company's business performance, (iii) leadership model is essential for working in a company? and (iv) the Personnel policy (staff selection and management) affects the company's business performance. Conducting the study, we used control questions to investigate differences in the importance of certain parameters between groups of respondents. Within the control question variable "Is motivation important for working in a company?", the Kruskal-Wallis hypothesis test revealed the presence of statistically significant difference in the perception of the following parameters: (i) Motivation affects a company's business performance; and (ii) Motivation affects a better working environment. Regarding the control question "Is the leadership model important for working in a company?", the Kruskal-Wallis hypothesis test has demonstrated a statistically significant difference in the perception of following parameters: (i) Motivation affects the company's business performance; and (ii) Leadership model affects the better working environment. The last variable we used to determine the population is the control question "Is the communication culture within a company important for working in that company?", with the statistical test resulting in statistically significant difference in the perception of parameters: (i) Motivation affects a better working environment; (ii) Leadership model affects the better working environment; (iii) Good communication affects the company's business success, and (iv) Leadership model affects the company's business performance.

Interestingly, part of the respondents evaluate the claims negatively: (i) whether motivation is essential for the company's work (3\%), (ii) whether the leadership model is important for work (3\%) and communication is essential for work (10\%). Although there are other studies that confirm the thesis that direct financial rewards such as wages are an outdated motivational factor, previous authors' research shows that "they are an important parameter in the private sector of the Republic of Croatia". In regard with the public sector, women emphasize "the importance of good business communication and satisfying working conditions", while men appreciate "acknowledgement from their colleagues and superiors, and recognition for a welldone job". Thus, in the previous survey, $35 \%$ of the respondents assigned salary as a motivational factor the highest rank.

Furthermore, we obtained the partial correlation coefficient for paired variables accounting for all three control variables. The results exposed the presence of statistically significant correlations between multiple variables, with all the coefficients being positive, and weak correlation was proven between following variables: (i) Good communication affects the company's business performance Leadership model affects the company's business performance; and (ii) Good 
communication affects the company's business performance and Leadership model affects the better working environment.

\section{Conclusion}

The conceptual model of this empirical research is aiming to describe the respondent's attitudes towards the influence of various parameters regarding the better business performance and working environment in the company. Furthermore, it also analyses the attitudes regarding the importance of motivation, leadership model and communication on employee satisfaction. Research question was designed around the importance of monitoring the employee satisfaction parameters in the public and private sector, which show that satisfied employees represent the main pillar of any organization's and company's development. Indeed, money and other financial rewards as instruments for motivation could have a short-term effect on employee satisfaction; however they can imply a significant factor in choosing future employment. By comparing the results of this research with results conducted over parameters affecting employees' satisfaction (Klopotan et al., 2016), there is "an obvious correlation in some theoretical aspects and also the results".

We argue that employee motivation has a significant impact on a better working environment, which is also the highest rated statement by employees. This result correlates with results from a previously mentioned research, confirming that parameters such as "acknowledgment for work well-done, respect by supervisors, job satisfaction, satisfying working conditions, good communication and collegial respect have a direct impact on the employee's satisfaction" (Klopotan et al., 2016). Moreover, besides the proposition that employee's motivation influences the working environment, it also has a direct impact on employee satisfaction, which ultimately contributes to a more successful performance.

Our empirical research results clearly pinpoint the link between successful application of motivational techniques, quality of the leadership and employee satisfaction. Overall, the results obtained by this research conducted from an employee point of view, detect the difference in the perception of the parameters of motivation, communication, leadership and personnel management, and their impact on employee satisfaction. We hope that our contribution will motivate further research on the role of motivation of employees and the importance of leadership.

\section{References}

1. Danish, R. Q., Khan, K. M., Shahid, A. U., Raza, I., Humayon, A. A. (2015), "Effect of intrinsic rewards on task performance of employees: Mediating role of motivation", International Journal of Organizational Leadership, Vol. 4, No. 1, pp. 33-46.

2. Horvat, J., Sharma, K., Bobek, S. (2015), "Knowledge Sharing and Performance Appraisal of Employees: a Pilot Case Study", Review of Integrative Business and Economics Research, Vol. 4, No. 3, pp. 62-73.

3. Jerry, R. H. (2013), "Leadership and Followership", University of Toledo Law Review, Vol. 44, pp. 345-354.

4. Jha, S., Bhattacharyya, S., Fernandes, C. (2016), „Human Resource Development Management \& Training as Antecedents for Strategy Integration", The Indian Journal of Industrial Relations, Vol. 52, No. 1, pp. 129-143.

5. Joo, B. K., Jeung, C. W., Yoon, H. J. (2010), "Investigating the influences of core selfevaluations, job autonomy, and intrinsic motivation on in-role job performance", Human Resource Development Quarterly, Vol. 21, No.4, pp. 353-371.

6. Kehoe, R. R., Wright, P. M. (2013), "The impact of high-performance human resource practices on employees' attitudes and behaviors", Journal of Management, Vol. 39, No.2, pp. 366-391. 
7. Kim, S., Feldt, L. S. (2008), "A Comparison of Tests for Equality of Two or More Independent Alpha Coefficients", Journal of Educational Measurement, Vol. 45, No. 2, pp. 179-193.

8. Klopotan, I., Buntak, K., Drožđek, I. (2016), "Employee Loyalty: Differences between Genders and the Public and the Private Sector", Interdisciplinary Description of Complex Systems, Vol. 14, No. 3, pp. 303-313.

9. Lazaroiu, G. (2015), "Employee Motivation and Job Performance", Linguistic and Philosophical Investigations, Vol.14, pp. 97-102.

10. Liu, B. C. (2009), "Evidence of Public Service Motivation of Social Workers in China", International Review of Administrative Sciences, Vol. 75, No.2, pp. 349-366.

11. Liu, B. C., Tang, N. Y., Zhu, X. M. (2008), "Public Service Motivation and Job Satisfaction in China: An Investigation of Generalisability and Instrumentality", International Journal of Manpower, Vol. 29, No. 8, pp. 684-699.

12. Liu, B., Ping Tang, T. L., Yang, K. (2015), "When does Public Service Motivation fuel the Job Satisfaction Fire? The joint Moderation of Person-Organization fit and Needs-Supplies fit", Public Management Review, Vol. 17, No. 6, pp. 876-900.

13. Mitreva, E., Filiposki, O. (2012), "Proposal methodology of the subsystem-internal standardization as part of TQM system", International Journal for Quality Research, Vol. 6, No. 3, pp. 251-258.

14. Moynihan, D. P., Pandey, S. K. (2007), "Finding Workable Levers over Work Motivation: Comparing Job Satisfaction, Job Involvement, and Organizational Commitment", Administration \& Society, Vol. 39, No. 7, pp. 803-832.

15. Rožman, M., Treven, S., Čančer, V. (2017), "Motivation and Satisfaction of Employees in the Workplace", Business Systems Research, Vol. 8, No. 2, pp. 14-25.

16. Vandenabeele, W. (2009), "The Mediating Effect of Job Satisfaction and Organizational Commitment on Self-Reported Performance: More Robust Evidence of the PSMPerformance Relationship", International Review of Administrative Sciences, Vol. 75, No. 1, pp. 11-34.

17. Yang, L. R., Huang, C. F., Hsu, T. J. (2014), "Knowledge Leadership to Improve Project and Organizational Performance", International Journal of Project Management, Vol. 32, No. 1, pp. 40-53.

18. Yoon, H. J., Sung, S. Y., Choi, J. N., Lee, K., Kim, S. (2015), "Tangible and Intangible Rewards and Employee Creativity: The Mediating Role of Situational Extrinsic Motivation", Creativity Research Journal, Vol. 27, No. 4, pp. 383-393. 


\section{About the authors}

Igor Klopotan, Ph.D. is a lecturer at the University North, Department of Business and Management. He received $\mathrm{PhD}$ in economy at the Faculty of commercial and business science in Slovenia with the dissertation thesis "Impact of Corporate Responsibility Communication over the Company web site and Social Networks to Business Reputation". He is the author and co-author of numerous domestic and international professional and scientific papers, and has participated in several international conferences. He is a member of the program committee of the international scientific conference Entrenova. The author can be contacted at: igor.klopotan@unin.hr.

Trina Mjeda works as an assistant at the University North in Croatia. She is currently engaged in a Ph.D. study program at the Faculty of Economics, University of Rijeka. During her doctoral studies, she is actively participating in numerous international seminars and workshops. As a guest lecturer, she was teaching at the University Rey Juan Carlos in Madrid in 2015, and at the University of Rijeka in 2017 and 2018. She had spent winter semester 2017/2018 at the Institute of Economics, Charles University in Prague, where she was trained in her academic work. She is fluent in English language, and also knows German, Spanish and Albanian language. Author can be contacted at trina.mjeda@unin.hr.

Dr. Petar Kurečić works as Assistant Professor of Political Science at the University North, Croatia. Dr. Kurecic is the author of one scientific book and numerous papers (fifteen in CC/WoS/Scopus indexed journals). His research interests are primarily geoeconomics, small states and small economies, and the challenges to European integration. He speaks fluent English and good German. He currently coordinates the work of the international research group "Small States in the Multi-Polar World". Dr Kurecic received several international mobility grants (ERASMUS+, CEEPUS) and is currently developing two EU projects. Author can be contacted at petar.kurecic@unin.hr. 